SoM Krisztián *

\title{
Állami útlevél-hamisítások történelmi példái
}

(Historical examples of state passport forgery)

\section{Absztrakt}

Az állami útlevélhamisítások a hamisítás legnehezebben fellelhető formái. Ezen hamisításoknak alapvetően kétféle fajtája alakult ki. Az egyik forma az, amikor az állam szervezetei idegen ország útlevelét hamisítják. A másik forma pedig az amikor az állam a saját útlevelébe jegyez be valótlan adatokat. Ez utóbbi felderítése rendkívül nehézkes. Az állami útlevélhamisítások jellemzője, hogy viszonylag csekély számban állítják elő ezen hamisított útleveleket és a tökéletes technikai kivitelezésükből fakadóan szinte lehetetlen a technikai úton való felderítésük. Az állami hamisításokkal szemben a biometriai eljárások sem nyújtanak védelmet, hiszen a valós biometriai adatokhoz kapcsolják a hamisítók az útlevelek eredetiségét biztosító megoldásokat.

\section{Kulcsszavak}

útlevélhamisítás ; állami útlevélhamisítás ; személyazonosság ; védlevél ; biometriai adatok

\section{Abstract}

State passport forgery is the most difficult form of forgery. There are basically two types of these counterfeits. One form is when state organizations forge a foreign country's passport. The other form is when the state enters false information in its own passport. The latter is extremely difficult to detect. State passport counterfeits are characterized by the fact that these counterfeit passports are produced in relatively small numbers and, due to their perfect technical execution, it is almost impossible to detect them by technical means. Biometric procedures also do not provide protection against government counterfeiting, as counterfeiters link solutions that ensure the authenticity of passports to real biometric data.

\section{Keywords}

passport forgery ; state passport forgery ; identity ; letter of protection ; biometric data

Open Researcher and Contributor ID = Nyílt Kutató és Közremüködő Azonosító (ORCID) : https://orcid.org/0000-0002-6993-2207

Institutional attachements $=$ Szerző intézményi kötödései :

- Bertalan Szemere Scientific Society of History of Hungarian Law Enforcement = Szemere Bertalan Magyar Rendvédelem-történeti Tudományos Társaság @: som.krisztian@hotmail.com

Date of registry $=$ Regisztrálás dátuma : 2018 . V. 17

Date of acceptance = elfogadás dátuma : 2018. VI. 30.

DOI : 10.31627/RTF.XXX.2020.59-60N.157-166P 
A z államok hírszerző szervezetei régóta közremüködnek abban, hogy személyek megváltoztathassák személyazonosságukat. Ez történhetett törvény adta felhatalmazás alapján, állampolgári igényre. A legáltalánosabb a férjezett név felvétele, vagy az örökbefogadáskori új családnév. Ritkább, de ide sorolandó a névváltoztatás, illetve Magyarországon még a visszahonosításkor a név (vissza)magyarosítása vagy egy magyar név választása. Ezen eljárás során a személyi adatok egyik legfontosabbikát, a születéskori nevet változtatják meg, de akár a születési hely településnevének magyar és az idegen nyelvü változata is eltérhet annyira, hogy az azonosságot idegen hatósági személy nem tudja felismerni. Az ilyen eltérések akár olyan következménnyel is járhatnak, hogy a körözési vagy beutazási tilalmat tartalmazó nyilvántartások adataival nem egyeztethetők. Ez különösen az útlevelek többségének szükebb adattartalma miatt tovább nehezedik.

Akadtak országok, amelyek az üldöztetés elől menekülők részére is lehetővé tették a személyazonosság cseréjét.

Állami hatóságok akaratából következik be személyazonosság-csere például azon országokban, ahol a tanúvédelemben részesülő személyeknek ezt biztosíthatják.

Ugyanígy állami hivatalok, felderítő szervezetek kellő felhatalmazás vagy érdekérvényesítési cél alapján változtatják meg a hírszerzésért és / vagy fedett müveletek végrehajtásáért felelős szervezetek külföldön tevékenykedő tagjainak személyazonosságát.

Ameddig ez saját állam okmányában történik, és már a saját államból kiutazáskor felhasználják az okmányt, akkor a közokirat-hamisítás büncselekmény nem feltétlenül valósul meg.

A közokirat-hamisítás egyik sajátos körülménye, amikor azt egy ország állami szolgálata, hivatala, hatósága, vagy annak tagja, a feladatkörüknek teljesítése érdekében hajtják végre. Ilyen eljárásokat általában biztonsági, politikai vagy humanitárius célból valósítanak meg. Akkor beszélhetünk ezen eljárások esetében közokirathamisításról, ha azok nyilvánosságra kerülnek.

Az állami hatóságok, szolgálatok részéről elkövetett közokirat-hamisítások tényleges okai, illetve az úti okmányok és a hamisítási módok változatosak voltak. A céljuk általában az, hogy valótlan személyazonossággal megtévesszék az úti okmányt ellenőrző idegen hatóságokat.

Az elkövetés tárgyát képezö úti okmány honosságát tekintve lehetett idegen, vagy a saját állam által kiállított. Utóbbi esetben jellemzően az okmány minden részében eredeti, csak az abban közölt adatok valótlanok. Ennek előnye abban rejlik, hogy a fényképen, személyleírásban szereplő személy valódi személyazonossága (és / vagy esetleg eltérő állampolgársága) rejtve maradhat az okmányt ellenőrző külföldi és hazai hatóságok előtt.

Az úti okmány felhasználási módját tekintve azok azonosak a ,polgári” életben előforduló esetekkel:

- eredeti úti okmány más személy általi, jogosulatlan felhasználása, azaz szakmai kifejezéssel személycsere;

- eredeti úti okmány meghamisítása, például a fénykép cseréje, vagy akár utazási előzmények hamisítása;

- eredeti úti okmány teljes utánzása;

- úti okmányba valótlan adatok rögzítése.

A középkorban még nem alkalmazták az úti okmányok általános kötelezettségét. Ennek ellenére azonban Magyarországon mégis felfedésre kerültek személyazonosság-cserék külföldi állami szolgálatban álló személyek esetében. Ezek közül az egyik legelső a német-római császár megbízásából 1027-ben Bizáncba tartó Werner strassburgi püspök volt. A feladata az volt, hogy a bizánci császár és megbízója között egy Magyarország elleni szövetséget hozzon létre. Útja — akárcsak a korban sok, Szentföldre zarándoklónak - Magyarországon vezetett keresztül. A magyar határra érkezésekor magát már zarándok szerzetesnek álcázta, azonban lelepleződött, így I. István király megtiltotta belépését hazánkba. ${ }^{1} \mathrm{Az}$ ilyen, és ehhez hasonló csalárd módokat megnehezítette az országhatárok átlépéséhez a XVIII-XIX. század fordulója tájékán a határátlépés feltételeként bevezetett általános és kötelező útlevélkényszer és az úti okmánynak előzetes, külképviseleti láttamozása (beutazási engedélyeztetése). Ebből fakadóan annak, aki valódi személyazonosságát elrejtve szeretett volna a határon átjutni, már az úti okmány hamisítását, vagy jogosulatlan felhasználását kellett megvalósítani.

Állami szolgálatok, hivatalok által megvalósított közokirat-hamisításra az elmúlt két évszázadban több esetben is fény derült.

Az állam által megvalósított útlevél-hamisítási és visszaélési tevékenységére nem csak az ismertté vált esetek adnak példát. A XIX. század utolsó harmadában az osztrák-magyar közös katonai hírszerző szolgálat, az Evidenzbureau szolgálati szabályzata alapján igyekezett más országok erede- 
ti okmányait megszerezni. Ezekkel majdan visszaélve kívánták biztosítani, hogy az osztrák-magyar felderítők és ügynökök valódi kiléte, állampolgársága rejtve maradjon akár háborús helyzetben is. ${ }^{2}$

Más állam úti okmányának jogosulatlan felhasználása azaz személycsere módszerrel megvalósított úti okmány hamisításra került sor például az Osztrák-Magyar Monarchia katonai hírszerzésének 1872-es szolgálati utasításában foglaltak szerint is. Az Evidenzbureau szolgálati utasítása ugyanis az ellenséges országba küldött ügynök idegen ország útlevelével történő ellátását írta elő. ${ }^{3}$

Az I. világháború egyik legelső, idegen állam úti okmányával történt visszaéléséhez kapcsolódó kémbotránya már a hadműveletek megindítását követő harmadik hónapban napvilágra került. Egy amerikai állampolgár újonnan — az akkor szabályok szerint még fénykép nélkül — kiállított útlevelét az azt kiállító amerikai külképviseletről jogosulatlanul elhozta az Egyesült Királyságban müködő német hírszerzési hálózat. A más nevére, de azonos személyleírásra szóló úti okmányt pedig, a tökéletes amerikai akcentussal beszélő német tartalékos fregatthadnagy használta fel személyazonossága igazolására, a brit haditengerészet mozgásának megfigyelése során. A német titkos ügynököt 1914. X. 2-án, Dublinban fogták el a brit hatóságok. Ez az eset vezethetett oda, hogy rövid idön belül a Föld sok állama kötelezővé tette az útleveleken a fényképek hitelesített csatolását, alkalmazását. ${ }^{4}$

Más állam úti okmánya tartalmának megváltoztatása módszerével megvalósitott hamisitás általában a lebukás kockázatát is magában foglalja. Az ilyen hamisításokra többnyire olyan helyzetben kerül sor, amikor titkos ügynökök valódi kilétét szeretnék elfedni. A források számos esetben hamis úti okmány felhasználásáról számolnak be, azonban vélhetően nem tesznek különbséget hamis (teljes utánzat) és hamisított (eredeti okmány egy, vagy több részletének jogosulatlan megváltoztatása) okmány között.

A Greenpeace nemzetközi környezetvédő szervezet Rainbow Warrior nevü hajója 1985. VII. 10-én az új-zélandi Auckland kikötőjében horgonyzott, amikor robbanás következtében félig elsülylyedt. (A szervezet hajója az akkori csendes-óceáni francia atomkísérletek elleni tiltakozás zászlóshajója volt.) A detonáció hatására egy portugál származású férfi is életét vesztette. Az Új-Zéland-i rendőrség nyomozása kiderítette, hogy a támadásért két francia állampolgár volt a felelős. A két francia személy — magukat házaspárnak kiadva — svájci útlevelekkel igazolta magát. A hamisítást vélhetően fényképcsere módszerével valósították meg. Ezután hamar az egyik francia titkosszolgálatra, a Külbiztonsági Főigazgatóságra (Direction Générale de la Sécurité Extérieure; DGSE) terelődött a gyanú, amelynek hivatásos tisztjei voltak az elkövetők. Az eljáró új-zélandi bíróság végül a nyomozás eredményeit bizonyítottnak látta. A francia elnök utasítására másodjára lefolytatott vizsgálat eredménye miatt a francia honvédelmi miniszter lemondott tisztségéről, továbbá a DGSE vezetőjét felmentették. ${ }^{5}$

A dél-koreai Korean Air Lines - 1987. XI. 29-ei KE-858 számú, Bagdad - Abu Dhabi - Bangkok Szöul útvonalon közlekedő - járatának Burma partjai előtt történt felrobbantásáért a nyomozás két északkoreai állampolgárságú ügynököt gyanúsított. A minden jel szerint a Koreai Népi Demokratikus Köztársaság szolgálatában és felsőbb vezetésének megbízásában álló idősebb férfi és fiatal nő még eredeti okmányaikkal érkeztek Budapestről Bécsbe, gépkocsival. Az osztrák fővárosban a budapesti észak-koreai öszszekötő ügynök két, hamisított japán útleveleket adott át nekik (a nő okmánya esetében vélhetően fényképcsere mellett adatok tartalmi hamisítása is lehetett, a férfiéban feltételezhetően csak előbbi beavatkozás történt). Az okmányokban szükséges japán kiléptető-bélyegzők lenyomatát az észak-koreai hírszerzés utánzás módszerével hamisította. Az elkövetők leleplezését követően felkért japán okmányszakértők véleménye szerint a japán útleveleket nagy igényességgel hamisították, ami szervezett elkövetés körülményeire utalt. A két észak-koreai ügynök — turistáskodó apa-lánya párnak álcázva —, a két hamisított okmánynyal kilépett Bécs-Schwechat repülőtéren, és repülőgéppel Belgrádba (Nándorfehérvár) utazott. E határátlépések sikerének feltétele volt, hogy az okmány adathordozó oldalainak meghamisításán túl utánzott osztrák beléptetö-bélyegzők lenyomatai is szerepeljenek. Így igyekeztek elkerülni, hogy a kilépéskor a hiányzó bélyegzőlenyomat miatt a hamisítás feltünjön az osztrák hatóságoknak. Néhány nap elteltével (mialatt a jugoszláv fővárosban megkapták a rádióba rejtett robbanószerkezetet) a belgrádi (nándorfehérvári) repülőtérről — ismét a korábban hamisított okmányokkal kilépve — megkezdték bonyolult útjukat Bahreinbe. ${ }^{6}$ A repült szakaszokat különböző légitársaságokkal tették meg Belgrád (Nándorfehérvár) és Bahrein között, amely hosszú, körülményes és költséges is volt. ${ }^{7}$ A két ügynök Abu Dhabiban — japán útlevelével — kiszállt a dél-koreai repülőgépből, amely hamarosan nélkülük folytatta útját. Az elkövetők ezután Abu Dhabiból légi járattal Manamába utaztak, ahol hamisított útleveleikkel beléptek Bahreinbe. Útjuk során összességében négy hatósági ellenőrzésen jutottak túl sikeresen. A Korean Air Lines Boeing 707-300-as repülőgépének Bengáli-öböl feletti robbanását követően hamar gyanússá vált a korábbi útszakasz két japán utasa. Ezután rendkívül rövid idő alatt kiderült — a Japánban lévő úti okmány nyilvántartásokat átvizsgál- 
va 一, hogy a női néven szereplő japán útlevelet meghamisították. Vélhetően az útlevél-nyilvántartás eltérő születési adatokat tartalmazott, vagy a név átírása esetén: azon a néven nem szerepelt kiadott okmány. A férfi okmányának vizsgálata során kiderült, hogy az útlevél tulajdonosa nem hagyta el Japánt a kérdéses időszakban. Azonban az útlevelét korábban kölcsönadta valakinek, akiről kiderült, hogy korábbi kémbotrány kapcsán Észak-Koreával hozták összefüggésbe. A hamisítások tényeiról értesített bahreini hatóságok, a két észak-koreai ügynököt a 1987. XII. 1-jei kilépésükkor feltartóztatták. Az okmányok alapos ellenőrzése, a személyek előállítása során az ügynökök öngyilkosságot követtek el. Azonban az elkövető nő azt túlélte, majd később részletes beismerő vallomást tett és halálra ítélte az eljáró bíróság. Kegyelem után börtönbüntetésre változtatták az ítéletet. ${ }^{8}$

Az izraeli Hírszerzés és Különleges Mủveletek Intézete (Ha-Mosszad leModi’in v'le-Tafkidim Mejuhadim, közkeletü nevén Moszad) számos külföldi müvelete során használta fel idegen államok hamis és hamisított útleveleit. Ilyen esetekre az 1970-es évektől több alkalommal is fény derült, komoly diplomáciai bonyodalmakat eredményezve. ${ }^{9}$ Azonban a Moszadnak a hamisított útlevelekhez kötődő nyilvánosságra került múveletei közül a legtöbbre 2010-ben került sor. A palesztin Hamasz (Harakat al-Mukavamah al-Iszlamijah) katonai szervezetének egyik alapító vezetőjét, Mahmúd AL-MABHUHot 2010. I. 20-án holtan találták egy Dubai-ban lévő szálloda szobájában. A rendőrségi nyomozás a természetes halálnak beállított gyilkossággal rövid időn belül 27 , az izraeli titkosszolgálathoz, a Moszadhoz köthető személyt gyanúsított. A 27 férfi és nő hamis (utánzott) vagy fényképcsere módszerével meghamisított tizenkettő brit, hat ír, négy francia és négy ausztrál, továbbá egy csalárd módon szerzett német útlevelet használt fel a többnemzeti nyomozás eredménye alapján. A gyanú szerint a brit útlevelek képeit és adatait akkor szerezhette meg az izraeli titkosszolgálat, amikor az eredeti tulajdonosok Izraelbe történő belépéskor akár 20 percre, alaposabb okmányvizsgálat ürügyével, az ellenőrzés helyszínéről elvitték az okmányokat. Ezeket az úti okmányokat már az Egyesült Arab Emírségekbe történő beutazásuk során is felhasználták. ${ }^{\mathbf{1 0}}$

Más állam úti okmányának teljes utánzás módszerével történö hamisitása került sor 1936 augusztusában, amikor a magyar belügyminiszter tudomására jutott, hogy a prágai csehszlovák állami nyomda — a csehszlovák hírszerző szolgálat felkérésére - megkezdte magyar útlevelek minőségi utánzására az előkészületeket. Az onnan eredő hamisítványok felfedésekor követendő eljárásokról a magyar határforgalom-ellenőrző hatóságok külön utasítást kaptak a minisztertől. ${ }^{11}$

Más állam okmányába valótlan adatok rögzitésére a történelem során csak néhány esetben került sor. A kiállító hatóság részéröl az igénylés során vagy azt követően a visszaélés felfedésére jellemzően, elvileg a XXI. századtól áll rendelkezésre hatékony eszköz számítógépes nyilvántartások formájában. Az úti okmányt ellenőrző hatóságok részéről ezek azonosítása nehéz feladat. Ennek oka, hogy az ellenőrzésre jogosult hatóság más állam nyilvántartásaiban szereplő adatbázishoz általában nem fér hozzá. Ilyen esetekben az okmány látszólag minden kritériumnak megfelel. A benne foglalt valótlan személyi adatok felfedésére legfeljebb gyanakvásra adhatnak okot. Ezen gyanú igazolására azonban csak a kiállító hatóság segítségével kerülhet sor.

Az új-zélandi nyomozás gyanúja szerint az izraeli Moszad titkosszolgálat két ügynöke 2004. márciusában új-zélandi útlevélhatóságtól kísérelt meg útlevelet szerezni egy mozgássérült férfi adatainak felhasználásával. ${ }^{12}$

A már említett, Mahmúd AL-MABHUH 2010. I. 19-ei Dubaiban elkövetett gyilkossága kapcsán az izraeli titkosszolgálathoz köthető gyanúsított eredeti és érvényes német útlevéllel több alkalommal is igazolta magát. A nemzetközi nyomozás megállapította, hogy az úti okmányt csalárd módon, valótlan tények és adatok közlésével (a majdani felhasználó fényképének csatolásával), egy titkosszolgálati közvetítő közbenjárásával szerezte meg a Moszad. Ezt az úti okmányt (is) az Egyesült Arab Emírségekbe történő beutazáskor és az ott a tartózkodás során is felhasználták. ${ }^{13}$

\section{Az útlevél hamisítás egyik lehetséges formája, amikor az állam saját okmányába valótlan ada- tokat rögzít.}

Erre a történelem során számos esetet és okot lehet találni. Az úti okmányt ellenőrző hatóságok számára ezek felfedése a legnehezebb. Ennek oka, hogy az okmányt az arra jogosult hatóság, az elöírásainak megfelelő módon személyesítette meg. Ebből eredően minden kritériumnak megfelel, a benne foglalt valótlan személyi adatok felfedésére legfeljebb gyanúoka lehet a határforgalmat ellenőrzőknek, azonban azt igazolni nehezen tudják, hiszen egy megkeresés kapcsán az azt kiállító állam a benne foglalt tartalmat valósnak fogja elismerni.

A valótlan információkat tartalmazó útlevél kiállításának humanitárius oka is lehet. Ebben az esetben az útlevelet abból a célból állítják ki, hogy egyének vagy néptömegek üldöztetése, életének 
veszélye elől menekítsenek személyeket. Ez esetekben általában az állampolgárság tényleges megadása nélkül adtak ki úti okmányt vagy annak hiteles kivonatát, látszólag saját állampolgárnak elismerve a nevezettet. Ezt néhány ismertté vált esetben a semleges államok külképviseleteinek munkatársai, vezetői honi hatóság felhatalmazása nélkül tették.

Udvardi és kossuthfalvi KOSSUTH Lajos, a magyar szabadságharc utolsó politikai vezetője az osztrák-orosz együttes támadás sikerei miatt, 1849 augusztusának második felében menekülni kényszerült Magyarországról. Törökországba álruhában és egy angol névre kiállított brit útlevéllel lépett be. Az immár száműzetésben élő KOSSUTH-házaspár 1852 júliusában szintén álnévre kiállított útlevéllel utazott az Egyesült Államokból az Egyesült Királyságba, hogy útjukat rejtsék az esetleges osztrák kémek előtt. Udvardi és kossuthfalvi KossuTH Lajos ezután is élvezte más államok védelmét és bizalmát, így részére francia útlevélhatóság is állított ki útlevelet 1859 májusában, amelyben a magyar államférfit dublini illetőségünek és „Georges Brown”-ként nevezte meg. (Abban az időben még előforduló eset volt, hogy egy ország más állam polgárai részére úti okmányt adott ki.) ${ }^{14}$

Az osztrákok által megszállt Magyarországról Udvardi és kossuthfalvi KOSSUTH Lajos felesége, született MESZLÉNYI Terézia Johanna menekülni kényszerült. 1849 december végén, Zimonyból Belgrádba (Nándorfehérvár) átkelését követően ő — a szerb belügyminiszter közbenjárására a belgrádi (Nándorfehérvár) brit főkonzul által, angol álnévre és illetőségre kiállított brit útlevéllel utazott Szerbiában, majd rövid tartózkodás után belépett azzal Törökországba. ${ }^{15}$

A németek által megszállt és a nekik politikailag elkötelezett magyar kormány által igazgatott Magyarországon 1944 nyarától, a háborúban semleges államok budapesti követségeinek munkatársa(i) a zsidó vallású magyar állampolgárok részére „védlevelet”, vagy ideiglenes csoportos útlevelet, úti okmány állítottak ki. A céljuk ezzel az volt, hogy az üldöztetés vagy deportálás elöl menekítsék őket. Ezekben az okmányokban azt közölték, hogy a nevezett személy(ek) az állampolgáruk, vagy az államuk által kiállított csoportos útlevélben szerepelnek, illetve esetenként azt, hogy országukba - rokoni kapcsolatok okán - beutazási vízumot szereztek. A svéd követség két munkatársa, 5000 útlevelet állított ki 1944 végéig és ugyanennyit a spanyol követség ügyvivője is, valamint a svájci követség tisztviselője és segítői — svájci külügyminisztériumi jóváhagyás nélkül — további 7000 védlevelet adtak ki. Ezen időszakban a Szent Szék (Vatikán) budapesti diplomáciai képviseletének vezetője is több száz oltalomlevelet hitelesített, amelyek közül a munkaszolgálatosoknak szántakat még azok megszemélyesítései előtt tett meg. A portugál követség két vezetője ügyvivője által kiállított védlevelek száma is elérte a több százat. ${ }^{16}$

1979 novemberében az iráni forradalom elől több mint félszáz amerikai állampolgár - sokuk a nagykövetségük alkalmazásában állt - nem tudott időben elmenekülni Teheránból. ${ }^{17}$ Míg legtöbbjüket irániak tartották fogságban, addig hatan különböző rejtekhelyeken, és más államok külképviseleteken leltek menedékre. A vallási alapokra és Amerikai Egyesült Államok-ellenes politikára helyezkedő új vezetés hatóságaitól nem remélhették, hogy biztosítják békés elutazásukat. Az amerikai Központi Hírszerző Ügynökség (továbbiakban CIA) bevonásával az USA kormányzata igyekezett valamilyen módot találni az Iránban rekedt állampolgáraik, diplomáciai alkalmazottaik kimenekítésére, majd hazaszállítására.

Az amerikai hírszerző szolgálat végül az a terv mellett döntött, hogy a kimenekítendöket egy alacsony költségvetésü kanadai film forgatócsoportjának állították be az iráni hatóságok előtt, akik fantasztikus filmjükhöz helyszínt kívántak keresni. (A fedőtörténet alátámasztására ÉszakAmerikában komoly hírverést szerveztek, és számottevő háttértevékenységeket is folytattak.) Közben az Egyesült Államok kormányzata a kanadai kormánnyal is megállapodásra jutott. Így 1980 legelején a teheráni kanadai nagykövetség - a kanadai parlament titkos határozata, felhatalmazása alapján - megkapta azon kanadai útleveleket, amelyek az amerikai diplomáciai alkalmazottak képmásait, de valótlan személyi adatokat tartalmaztak. Az útlevelek - a meg-nem-történt határátlépés „igazolására” - utánzott iráni vízumot és utánzott iráni beléptető-bélyegző lenyomatot tartalmaztak, amelyet a CIA Iránba utazott munkatársai készítettek el Teheránban. Ehhez egy kanadai ismerős útlevelében lévő eredeti iráni vízumbélyegzö-lenyomatot, illetve az amerikai ügynökök által használt útlevélbe, a teheráni érkezéskor kapott eredeti beléptető lenyomatot használták mintaként. (A kimenekítendő hatfős csoport ellátására 12 kanadai útlevél állt rendelkezésre [például felmerülő hamisítási hiba esetére], a biztonság kedvéért még 12 USA úti okmány is a helyszínen volt.)

A csoport elutazását úgy időzítették, hogy az az iráni elnökválasztások utáni várhatóan oldottabb hangulatban folytatott ellenőrzés első napjaira essen. Ezen kívül - a várható iráni válaszlépés miatt - egyidejüleg Kanada teheráni nagykövetségét felszámolták, és annak végleges bezárását a müvelet napjára elvégezték. A hamisított útlevelekkel rendelkező csoport 1980. január 28-án (a 
választást követő második napon) kilépésre jelentkezett a teheráni nemzetközi repülőtéren, s az útlevél-ellenőrzésen sikeresen átjutottak. A hat amerikai a Teheránból Zürichbe tartó menetrend szerinti Swissair járattal repült Európába. Ezzel közel egy időben a kanadai külképviseletet addig müködtető négy diplomata is távozott Iránból. A leszállást követően, a Svájcba megérkezett hat amerikai a kanadai útleveleiket egy CIA ügynöknek adták át. Kanada szerepe hamar napvilágra került, az iráni külügyminisztérium is már január 29-én értesült a történtekről és éles bírálatot fogalmazott meg Kanadával szemben. ${ }^{18}$ Az eset az Irán és Kanada közötti viszonyt hosszú időre elhidegítette. (Azonban a nyugati világban nem okozott kedvezőtlen visszhangot, még az akkori Magyarországon is csak tényekre szorítkozó, minősítés nélküli cikkeket közöltek az esetről.)

Ugyanebbe a csoportba tartozik a magyar szabadságharc végén történt egyik eset is. Azonban itt a valótlan adatokkal való kitöltést az úti okmányt felhasználóra bízta az útlevelet hitelesítő személy.

A volt magyar miniszterelnök, szemerei SzEMERE Bertalan utolsó magyarországi tartózkodása során, Orsován szert tett Belgrádból (Nándorfehérvár) megküldött hét külföldi, hitelesített, de még kitöltetlen útlevélre. Ezeket majd Vidinben (Bodony) tartózkodása idején, egyet magának fenntartva, sorstárai rendelkezésére bocsájtotta, akik céljuknak megfelelően megszemélyesítették azokat. ${ }^{19}$

Végül e csoportba kívánkozik egy másik eset is, amikor azért adtak jog szerinti állampolgárságot és új nevet, hogy megtévesszenek ezáltal idegen hatóságokat.

Nagyrápolti SZENT-GYÖRGYI Albert - az 1930-as évek végére már világhírü magyar tudós 1944. tavaszától Budapesten bujkálni volt kénytelen, mivel a német Titkos Államrendőrség (Geheime Staatspolizei; rövidítve: Gestapo) mindenhol kereste. Ö és felesége Svédország budapesti követségén kapott menedéket, azonban sejtették, hogy a német titkosrendőrség hamar kideríti tartózkodási helyét. A svéd követ közbenjárására rövid időn belül svéd állampolgárságot szereztek, $s$ új névre, „SWENSON” családnévvel kiállított útlevelet kaptak. ${ }^{20}$ Bár ezzel az eljárással a svéd külképviseleti hatóság nem követett el jogsértést, azonban a szándéka egyértelmú volt: félrevezetni német és magyar hatóságokat a menekülö tudós és felesége biztonsága érdekében.

A valótlan adatokat tartalmazó útlevél kiállításának az is lehet az oka, hogy egy állampolgárságot szerzett, korábban menekült személy személyazonosságát rejtsék abban az esetben, ha az útja származási helyére vezetne, vagy származási országának titkosszolgálata üldözné, akkor eredeti adatai ismeretlenek maradjanak. Ez részben történhetett a személy hivatalos és végleges névváltoztatási eljárása keretében is, azonban ez esetben büncselekmény nem történik. A korábban már említésre került udvardi és kossuthfalvi KOSSUTH és felesége, valamint SZEMERE és társai esete ide is illeszkedik.

TELEKI László gróf az 1848-1849-es magyar forradalom és szabadságharcban kifejtett tevékenysége miatt — többek között gróf németújvári BATTYHÁNY Lajos Ferenc József kormányának párizsi követe volt — az Egyesült Királyságban élt az 1850-es években. 1860 novemberében John HAROLD álnévre kiállított brit útlevéllel ${ }^{21}$ utazott a szász fơvárosba, Drezdába, hogy ott élö magyar hölgyismerősét felkeresse. ${ }^{22}$ A szász rendőrség a fővárosban mindvégig megfigyelés alatt tartotta, majd visszautazásának reggelén, december 16-án letartóztatták és négy nap múlva a szász-osztrák határra szállították, ahol átadták az osztrák hatóságoknak az azok által körözött magyar grófot. A szász hatóságok eljárása miatt nyugat-európai kormányok tiltakoztak, amely ellentétes volt már az akkori nemzetközi jogi gyakorlattal is.

A valótlan adatokat tartalmazó útlevél kiállításának az oka lehet továbbá egy állampolgár, vagy egy fedett ügynök rejtése, hogy valódi — esetleg korábban gyanúba vagy látókörbe került - személyazonossága titkolva maradjon. Ezen elkövetési mód igen nehezen felfedhetö, hiszen maga a kiállító állam hatósága valósítja meg eredeti okmányürlapon, az okmánykiállítás minden alaki és tartalmi kellékével.

Az ,átlagos” állampolgárok esetében ezek több okból is előfordulhatnak, amelyek között szerepelnek az úgynevezett védett tanúk valódi személyazonosságának elrejtése is. Azonban ez utóbbi esetben nem cél más állam megtévesztése, illetve az jogszabályi felhatalmazás alapján, az abban lefektetett keretek között történik.

A valótlan adatokat tartalmazó útlevél kiállításának oka lehet még egy másik ország védelmét élvező személy elrablása, hogy saját vagy szövetséges állam területére szállítsák. Ezen elkövetési módhoz általában valótlan adatokra, de az elrabolt személy arcképével ellátott saját útlevelét használják fel, a kivitelezés sok esetben megkívánja, hogy az okmányt szükség esetén vízummal lá(tta)ssák el, illetve a valóságban meg-nem-történt határátlépést utánzott beléptető-bélyegző lenyomattal ,,igazolják".

Otto Adolf EICHMANN a III. Német Birodalom állampártjának vezető tagja, az európai zsidók üldözésének egyik fő szervezője volt 1945-ig. A háború után sokáig bujkált a hatóságik elől, majd 1950- 
ben Ricardo KLEMENT álnévre igényelt okmánnyal és vízummal Argentínába költözött. 1959 végén a háborús bünökkel gyanúsított Otto Adolf EICHMANN által használt álnevet és tartózkodási helyét sikerült beazonosítani az izraelieknek. Izrael Állam titkosszolgálata, a Moszad ezt követően néhány hónap során adatokat gyüjtött a célszemélyröl a helyszínen, és további nyomozásokat folytatott a személyazonosság biztos megállapítása végett. Három izraeli titkos ügynök még 1960 áprilisban megérkezett az argentin fővárosba, ahol Otto Adolf EICHMANNt, rendszeres tevékenységeinek elemzése után, 1960. V. 11-én este elfogták. Az országból történő kicsempészését előre kidolgozták. Ennek egyik részleteként az egyik ügynök - megtévesztéssel - argentin korházból orvosi igazoláshoz jutott, hogy a nevezettet betegsége enyhülésére való tekintettel, 1960. V. 20-án hazautazni engedték. ${ }^{23}$ A német háborús bünös elrablását egy hivatalos izraeli küldöttség argentínai látogatásához időzítették, amely az El Al izraeli légitársaság különjáratával érkezett Dél-Amerikába. A három ügynök az elfogott és fogva tartott személyt 1960. V. 21-én elkábította, hogy megelőzzék az esetleges ellenállását és a lábadozó bódultságának látszatát keltsék. Ezt követően az izraeli El Al légiutas-kísérőjének öltöztették be, hogy mint a légitársaság repülögép személyzetének tagja hagyja el a dél-amerikai országot. A Buenos Airesi repülötéren az ügynökök sikeresen átjutatták a kábult Otto Adolf EICHMANNt, a személyzeti bejárónál őrt álló jóhiszemüségét kijátszva. A fogoly ellenőrzése estére, korábban az ő arcképével, de kitalált személy adataira Zeev ZICHRONI névre - kiállított izraeli útlevet csináltattak és tartottak kéznél. A férfit az izraeli légitársaság kormányzati különjáratával — rövid dakari műszaki leszállást közbeiktatva — Izraelbe szállították, ahol hamarosan bíróság elé állították. Az eset kapcsán Argentína hevesen tiltakozott, a belügyeibe történt beavatkozásként értékelte az eseményeket, és ezért az Egyesült Nemzetek Szervezetének Biztonsági Tanácsához fordult. A kivitelezés részleteinek látszata ellenére is, Izrael hivatalos nyilatkozata szerint az emberrablók magánszemélyek voltak, saját elhatározásukból cselekedtek. A két ország még 1960-ban békés úton tisztázta az esetet.

Kiállító hatóság(ok), állami szolgálatok tudomása nélkül nem csak ,átlagemberek”, hanem leendő vagy volt államfők is felhasználtak hamis / hamisított útlevelet határátlépésük megvalósításához.

Az ok általában az útba ejtett vagy célország hatóságai előtt a valódi személyazonosság eltitkolása volt.

A 27 éves Karl Eitel Friedrich Zephrynus Ludwig von HOHENZOLLERN-SiGMARINGEN herceg - a későbbi I. Károly román fejedelem, majd király —, 1866 áprilisában elfogadta a román országgyülés által felajánlott román fejedelmi trónt. Ekkorra Ausztria és Poroszország között igen feszülté vált a helyzet, mivel a porosz kormány már nyíltan osztrák-ellenes szövetségeket kötött a „nagynémet” törekvéseken dolgozó bécsi kormányzat ellen (ez majd június közepén hadiállapothoz vezetett). Ezért Karl Eitel Friedrich Zephrynus Ludwig von HOHENZOLLERN-SIGMARINGEN - az egyedüli megoldásként - üzletembernek öltözve, valótlan nevére (álnévre) szóló útlevéllel utazott át az osztrák tartományokon és Magyarországon. A közvetítő útján megszerzett svájci úti okmány Karl HETTINGEN névre, de a herceg személyleírásával (mint „magánzó”) és odesszai utazási céllal került kiállításra, amelyet átadva/felhasználva lépett osztrák földre. Ezután útját két utastársával, másodosztályon zavartalanul folytatta Bécsbe, majd Buda-Pestre ahonnan lehajózott a Duna magyarországi szakaszán. Magyarországról - a valótlan adatokra kiállított útlevél felhasználásával — Orsovánál kilépett, s beutazott román földre. ${ }^{24}$ Románia fejedelme 1866. V. 10től, Bukarestbe bevonulásától lett.

Az ,államügyek vitelétől” visszavonult $I V$. Károly osztrák császár és magyar király a két és fél évnyi svájci számüzetéséből vissza kívánt térni, s ezért 1921. kora tavaszán Magyarországra indult. A korábbi király célja akkor az államföi hatalom visszaszerzése volt. Személyazonossága rejtése érdekében, 1921. márciusi útja során, álruhában és kíséret nélkül, Németországba és Ausztriába történő be- és kilépés során egy A. SANCHEZ névre kiállított, 792. sorszámú spanyol útlevéllel igazolta magát. Magyarországra Bécsből, a Pinkafö-Szombathely útvonalon, Bucsunál utazott be ${ }^{25}$ Ezen időszak eseménysorozata később az „első királypuccs” néven vonult be a magyar történelembe.

KIM Dzsong-nam feltehetően két esetben is, három útja során követett el közokirat-hamisítást. Ö volt KIM Dzsong-il, a volt észak-koreai államfő legidősebb fia, aki 2001-ben még a valószínű várományosa volt az észak-koreai politikai vezetésnek.

KIM Dzsong-nam — két hölgy és egy négyéves gyermek társaságában — a Koreai Népi Demokratikus Köztársaságból légi úton, pekingi átszállást követően, 2001. V. 1-jén érkezett meg a Tokió Új Nemzetközi Repülőtérre (ma Narita Nemzetközi Repülőtér). Ott, a beléptető határforgalom-ellenőrzés során más névre szóló hamisított dominikai köztársasági útlevelet adott át a japán útlevélkezelőnek, akárcsak útitársai. Szándékuk, elmondásuk szerint az volt, hogy Japánban felkeressék az Urayasu-i Disneylandet. Az úti okmányokért, szintén nyilatkozat szerint KIM Dzsong-nam darabonként 2000 amerikai dollárt fizetett. A japán hatóságok beléptetésüket megtagadták, majd 
2001. V. 4-én visszairányították öket a Kínai Népköztársaságba. ${ }^{26}$ KIM Dzsong-nam vélhetően ez az eset miatt került háttérbe az észak-koreai hatalom várományosai köréböl.

KIM Dzsong-nam apja, KIM Dzsong-il 2011. XII. 17-ei halálhíréről értesülve Makaóról, kínai átszállással a Koreai Népi Demokratikus Köztársaságba utazott más névre kiállított útlevéllel, majd néhány nap múlva ezen útlevéllel visszatért korábbi tartózkodási helyére. ${ }^{27}$

\section{Jegyzetek:}

${ }^{1}$ Som: A magyar határforgalom ellenőrzés, 1000-1301.

${ }^{2}$ BODA - PARÁDI - REGÉNYI: 73.p. + 103-104.p.

${ }^{3}$ Loc.cit. 103-104.p.

${ }^{4}$ A német haditengerész tiszt Carl Hans Lody tartalékos fregatthadnagy volt.

SoM: A magyar úti okmányok 1848-2012. 73-74.p. + 182-183.p.

${ }^{5}$ Az elkövetőket gondatlanságból elkövetett emberölés és gyújtogatás miatt 10-10 év szabadságvesztésre ítélték. Franciaország a kiadatás megtagadása miatt elérte az Európai Gazdasági Közösségnél az új-zélandi termékekre a behozatali tilalom bevezetését. Ez erős, gazdasági nyomást gyakorolt a szigetállamra. Az Egyesült Nemzetek Szervezete főtitkárának közbenjárására, az import-tilalom feloldásáert cserében, végül 1986 nyarán Francia Polinéziába szállították a két titkos ügynököt, akiknek ott három év szigorított katonai szolgálatot kellett letölteniük.

KÖVES ; LÁSZLÓ ; Új-Zéland hazaengedi a francia ügynököket.

${ }^{6}$ Az Iraqi Airways által teljesített Belgrád (Nándorfehérvár) - Bagdad útvonal után, 3 órás átszállásra várakozást követően, légitársaságot váltottak. Ekkor a Korean Air Bagdad - Abu Dhabi közötti járatával utaztak tovább, majd újabb 6 órás csatlakozási idő elteltét követően, a Gulf Air Abu Dhabi - Bahrein járatával érkeztek meg Manamába.

SZABÓ: 125-131.p.

${ }^{7}$ Korabeli vizsgálatok alapján, lényegesen olcsóbb és időben is rövidebb lett volna a Belgrád (Nándorfehérvár) Amman / Amman-Bahrein útvonal.

${ }^{8}$ SZABÓ: op.cit. 125-131.p.

${ }^{9}$ A Palesztin Felszabadítási Szervezet bejrúti irodája 1973. évi megrohamozásának kivitelezése érdekében az izraeli Moszad három ügynöke brit hamis(ított) útlevelet használt fel utazásai során. Szintén 1973-ban - a müncheni olimpiai faluban elkövetett merénylet elkövetői elleni bosszúhadjárat keretében - az izraeli titkosszolgálat több ügynökét elöállították, miután megöltek egy marokkói férfit, akiröl tévedésböl azt hitték, hogy azonos az egyik elkövetővel. Az egyik női ügynök hamis(ított) kanadai útlevelet használt fel, míg a többi brit és francia úti okmányok birtokában utazott be Norvégiába.

A Moszad egy másik női ügynöke 1979-ben egy gépkocsiba rejtett bombával követett el merénylet Bejrútban, az utazása során hamis(itott) brit útlevelet használt.

Nyugat-Németországban, 1986 nyarán egy telefonfülkében hagyott táskában eredeti izraeli útlevél és Izrael egyik nagykövetségére utaló iratok társaságában 8 hamis(ított) brit útlevelet felejtettek. Ezeket, korabeli gyanú szerint, izraeli titkos ügynököknek szánták.

Két izraeli titkos ügynök 1997. IX. 25-én merényletet kísérelt meg Khaled MESHAL, a palesztin Hamasz egyik vezetője ellen. Az izraeliek ez esetben is hamisított kanadai útlevéllel utaztak be Jordániába.

A Moszad magára vállalta. ; Harc az útlevelekért. ; Hamis útlevéllel álcázott kémek.

${ }^{10}$ Elkábították az áldozatot. ; KePECS ; Kiutasították a Moszad-rezidenst. ; Kiutasítva. ； London kiutasított egy izraeli diplomatát a dubaji rajtaütés miatt.

${ }^{11}$ SoM: A magyar határforgalom ellenőrzés, 1000-1301. 82.p.

12 Moszad-ügynököket büntettek. ; SITKEI

${ }^{13}$ LÁZÁR: 8.p.

${ }^{14}$ Som: A magyar úti okmányok 1848-2012. op.cit. 53-54.p.

${ }^{15}$ Loc.cit.

${ }^{16} \mathrm{Az}$ életmentő hamisított útlevelek kiállításában a svéd követség két munkatársa Carl Ivan DANIELSSON és Raoul WALLENBERG követségi titkár, továbbá a spanyol követség ügyvivője Angel SANZ-BRIZ, a svájci követség tisztviselöje Carl LuTz, továbbá Angelo RotTA a Szent Szék budapesti képviselője pápai nuntius, a portugál követség részéről pedig Carlos Sampaio GARRIDo követ és Alberto Carlos BRANQUiNHO ügyvivő vettek részt.

${ }^{17}$ Iránban, de különösen Teheránban 1978. őszén egyre terebélyesedett az iszlám forradalom, amely majd idővel az amerikai érdekeltségek elleni támadásokban is megnyilvánult. A forradalmi vezetés 1979. januárjában átvette a kormányzást, majd hagyta, hogy 1979. november 4-én diákok népes csoportja megrohamozza és megszállja az Amerikai Egyesült Államok (USA) teheráni nagykövetségét, s az ott tartózkodókat fogva tartsák.

${ }^{18}$ Elnökválasztás után. ; GeRVAIS ; Iránban bezárták az amerikai bankok fiókintézeteit.

${ }^{19}$ Som: A magyar úti okmányok 1848-2012. op.cit. 53-54.p.

${ }^{20}$ TASINÉ - TASI

${ }^{21}$ LUKÁCS

${ }^{22}$ Cs. Lengyel ; SOLymos

${ }^{23}$ BLACK - MORRIS: 168-205.p.

${ }^{24}$ Károly király útlevele. ; SANBORNE: 31.p.

${ }^{25}$ BÉKÁSSY ; SIMOLA

${ }^{26}$ Kim Dzsong Nam titkos gyásza.

${ }^{27}$ Loc.cit. 
Forrás-és irodalomjegyzék (a jegyzetekben alkalmazott röviditések oldása):

\section{MONOGRÁFIÁK KISMONOGRÁFIÁK ÉS HASONLÓ JELLEGÜ KÖTETEK}

BÉKÁSSY

(25.;)

BLACK - MORRIS

(23.;)

BODA - PARÁDI - REGÉNYI (2.;3.;)

SANBORNE

(24.;)

SoM: A magyar úti okmányok 18482012.

(4.;14.;15.;19.;)

SZABÓ

$(6 . ; 8 . ;)$

\section{TANULMÁNYOK}

LUKÁCS

(21.;)

SoM: A magyar határforgalom ellenőrzés, 1000-1301.

(1.;11.;)

TASINÉ - TASI

(20.;)

\section{CIKKEK}

CS. LENGYEL

Elkábították az áldozatot

(10.;)

Elnökválasztás után.

(18.;)

GERVAIS

(18.;)

Hamis útlevéllel álcázott kémek.

(9.;)

Harc az útlevelekért.

(9.;)

Iránban bezárták az amerikai bankok fiókintézeteit.

(18.;)

Károly király útlevele.

(24.;)

KEPECS

$(10 . ;)$
BÉKÁssy Jenő et al. (szerk.): Zala vármegye feltámadása Trianon után. (Zalai fejek.) Budapest, 1930, Hungária Hírlapnyomda Részvénytársaság. $463 \mathrm{p}$.

- Ian BLACK - Benny MorRIs: Israel's secret wars. A history of Israel's intelligence services. [Izrael titkos háborúi. Az izraeli titkosszolgálat története.] New York, 1991², Grove Press. 634 p. USA-ISBN 0802132863.

— BODA József — PARÁdi József — REGÉNYi Kund Miklós (szerk.): 1872 Felderitö-szolgálati utasitás. Anleitung zum Kundschaftsdienste. Budapest, 2014, Nemzetbiztonsági Szakszolgálat - Szemere Bertalan Magyar Rendvédelem-történeti Tudományos Társaság. 441 p. HU-ISBN 978963 898284 1. /A magyar rendvédelem-történet hagyatéka, 1./ HU-ISSN 2064-4728.

- Mark SAnBorne: Nations in transition. Romania. [Nemzetek átmenetben. Románia.] New York, 2004², Facts on File Inc. 181 p. USA-ISBN 0816050821 .

- Som Krisztián: A magyar úti okmányok 1848-2012. Budapest, 2014, Nemzetbiztonsági Szakszolgálat - Szemere Bertalan Magyar Rendvédelem-történeti Tudományos Társaság. 337 p. HU-ISBN 9789638982834. /Segédtudományok a magyar rendvédelem-történet szolgálatában, 1./ HUISSN 2064-5333.

- Szabó Miklós: Légi katasztrófák. Terror a levegőben - megrázó tragédiák 1968 és 2004 között. Jogellenes cselekmények Sárga Könyve 1968 2004. Pécs, 2006, Alexandra Kiadó. 337 p. HU-ISBN 9633700280.

- LuKÁCs Lajos: Teleki László elfogásától öngyilkosságáig és a nemzetközi diplomácia. 112-116. p. In PRAZNOvsZKY Mihály - RozSNYói Ágnes (szerk.): Teleki és kora. Szirák 1985. november 12-13. Salgótarján, 1987, Nógrád Megyei Múzeumok Igazgatósága. 176 p. HU-ISBN 9630180138 /Discussiones Neogradienses, 3./ HU-ISSN 0236-7041.

- Som Krisztián: A magyar határforgalom ellenőrzés, 1000-1301. 103120.p. In PARÁDI József et al. (szerk.): Ünnepi tanulmányok GÁSPÁR László 65. születésnapja tiszteletére. Budapest, 2015, Szemere Bertalan Magyar Rendvédelem-történeti Tudományos Társaság. 154 p. HU-ISBN 978 6158030908 /Salutem, 1./ HU-ISSN 2416-2078.

- TAsinÉ Csúcs Ildikó - TASI Domonkos Attila: Szent-Györgyi Albert visszaemlékezése életéről, munkájáról, koráról. Magyar Tudomány, CLXXVIII.évf. (2017) 7.sz. 828-839.p. HU-ISSN 0025-0325.

- Cs. Lengyel Beatrix: Teleki László - az Országgyülés halottja. Kiállítás a Magyar Nemzeti Múzeumban. História, XXXIII.évf. (2011) 8.sz. 26.p. HU-ISSN 0139-2409.

— Elkábították az áldozatot. Magyar Szó, LXVII.évf. (2010) 48.sz. (március 1.) 2.p. SK-ISSN 0350-4182.

- Elnökválasztás után. (Szerkesztőségi közlemény.) Magyarország, XVII.évf. (1980) 5.sz. (II. 3.) 5.p. HU ISSN 0464-4956.

- Marty GeRvaIs: Iran rescue: Our bashful heroes. [Iráni mentés: szégyenlős höseink.] The Windsor Star, XCIII évf. (1981) 75sz. (III. 28.) 8.p. CA-ISSN 0839-2277.

- Hamis útlevéllel álcázott kémek. Magyar Szó, XLIV.évf. (1987) 74.sz. (március 17.) 4.p. SK-ISSN 0350-4182.

- Harc az útlevelekért. (Szerkesztőségi közlemény.) Magyar Nemzet (budapesti kiadás), LXXIII.évf. (2010) 49.sz. (február 19.) 8.p. HU-ISSN 0133-185X.

- Iránban bezárták az amerikai bankok fiókintézeteit. (Szerkesztőségi közlemény.) Népszava, CVIII.évf. (1980) 25.sz. (I. 31.) 2.p. HU ISSN 01331701.

- Károly király útlevele. (Szerkesztőségi közlemény.) Budapesti Hírlap, XXVI.évf. (1906) 106.sz. (IV. 18.)

- KePECS Ferenc: Halál egy dubaji luxusszállodában. Népszava, CXXXVII.évf. (2010) 48.sz. (február 26.) 13.p. HU-ISSN 0133-1701. 
Kim Dzsong Nam titkos gyásza. $(26 . ; 27 . ;)$

Kiutasították a Moszad-rezidenst. (10.;)

Kiutasítva.

(10.;)

Köves

(5.;)

LÁSZLÓ

$(5 . ;)$

LÁZÁR

(13.;)

London kiutasított egy izraeli diplomatát a dubaji rajtaütés miatt. (10.;)

A Moszad magára vállalta.

(9.;)

Moszad-ügynököket büntettek.

(12.;)

SimOLA

(25.;)

SITKEI

(12.;)

Új-Zéland hazaengedi a francia ügynököket.

(5.;)

\section{FORRÁSKIADVÁNYOK}

SOLYMOSI

(22.;)
- Kim Dzsong Nam titkos gyásza. (Szerkesztőségi közlemény.) Somogyi Hírlap, XXIII.évf. (2012) 3.sz. (I. 4.) 11.p. HU-ISSN 0865-9125.

- Kiutasították a Moszad-rezidenst. (Szerkesztőségi közlemény.) Népszabadság (budapesti kiadás), LXVIII.évf. (2010) 69.sz. (március 24.) 7.p. HU-ISSN 0133-1752.

- Kiutasítva. (Szerkesztőségi közlemény.) Magyar Szó, LXVII.évf. (2010) 118.sz. (május 25.) 2.p. SK-ISSN 0350-4182.

- Köves Judit: Az évszázad pere elmaradt. Népszava, CXIII.évf. (1985) 275.sz. (november 23.) 2.p. HU-ISSN 0133-1701.

- LÁszló Balázs: A Rainbow Warrior-ügy záróakkordja. Tolna Megyei Népújság, XXXVI.évf. (1986) 160.sz. (július 9.) 2.p. HU-ISSN 01330551.

- LÁzÁr Stefan: A Moszad trükkje miatt dühös Berlin. Magyar Nemzet (budapesti kiadás), LXXIII.évf. (2010) 193.sz. (július 17.) 8.p. HU-ISSN 0133-185X.

- London kiutasított egy izraeli diplomatát a dubaji rajtaütés miatt. (Szerkesztőségi közlemény.) Magyar Hírlap, XLIII.évf. (2010) 69.sz. (március 24.) 11.p. HU-ISSN 1786-478X.

— A Moszad magára vállalta. (Szerkesztőségi közlemény.) Új Magyarország, VII.évf. (1997) 234.sz. (október 7.) 1-2.p. HU-ISSN 1215-0185.

- Moszad-ügynököket büntettek. (Szerkesztőségi közlemény.) Népszava, CXXXII.évf. (2004) 165.sz. (július 16.) 2.p. HU-ISSN 0133-1701.

- Simola Ferenc: A pinkaföi banánhéj. Határőr, LX.évf. (2005) 4.sz. 29.p. HU-ISSN 1419-5380.

- SitKeI Levente: Új-Zéland utat mutat. Magyar Nemzet (budapesti kiadás), LXVIII.évf. (2004) 184.sz. (július 17.) 7.p. HU-ISSN 0133-185X.

Új-Zéland hazaengedi a francia ügynököket. Magyar Hirlap, XIX.évf. (1986) 166.sz. (július 16.) 2.p. HU-ISSN 0133-1906.

Solymosi József et al. (szerk.): „Barátja, Kossuth”. Forráskiadvány Kossuth Lajos Hadtörténelmi Levéltárban és Hadtörténeti Múzeumban örzött irataiból. Budapest, 2003, Hadtörténelmi Levéltár - Petit Real Könyvkiadó. 211 p. HU-ISBN 9639267007 /Hadtörténelmi Levéltári Kiadványok./ HU-ISSN 1417-9598. 